\title{
The Biologic Activities of Cystic Fibrosis Serum. II. Ultrastructural Aspects of the Effect of Cystic Fibrosis Sera and Calcium Ionophore A23187 on Rabbit Tracheal Explants
}

\author{
BRUCE IAN BOGART ${ }^{49)}$ \\ Department of Cell Biology, New York University Medical Center, New York, New York, USA \\ ELAINE J. CONOD \\ Department of Pediatrics, Albert Einstein College of Medicine, Bronx, New York, USA \\ PUREZA F. GAERLAN \\ Department of Pediatrics, College of Physicians and Surgeons, Columbia University, New York, New York, USA \\ JAMES CONOVER \\ Department of Pediatrics, Albert Einstein College of Medicine, Bronx, New York, USA
}

\begin{abstract}
Summary
Ultrastructural and cytochemical observations indicate that both cystic fibrosis (CF) sera and calcium ionophore $\mathbf{A} 23187$ induce a swelling or an increase in the size and possibly the number of secondary lysosomes and an increase in mucus secretion in epithelium of the rabbit tracheal bioassay system. Extended incubation of the rabbit tracheal explants with either CF or control sera produces a cytotoxic effect on the tracheal epithelium, but only after the termination of the normal bioassay time period. Comparative ultrastructural study of the effect of both CF sera and calcium ionophore $A 23187$ on the rabbit tracheal bioassay system indicates that increased membrane permeability to calcium may be important in the production of the ciliary dyskinesia response by CF serum factor(s) in the rabbit tracheal bioassay system.
\end{abstract}

\section{Speculation}

CF serum factor(s) may be acting on the cultured rabbit tracheal explant epithelial membranes to produce altered membrane permeability to ions and to calcium in particular. This alteration in membrane function may be promoting the observed ultrastructural changes in the epithelial cells which include a swelling or increase in the number and size of secondary lysosomes and an increase in mucus secretion as well as ciliary dyskinesia. Alterations in membrane function and permeability may be related to the pathophysiology of this genetic disorder.

Cystic fibrosis (CF) is an autosomal recessive disease that is characterized by the dysfunction of many exocrine glands $(16$, 28 ). Although accurate evaluation of elevated sodium chloride levels in the sweat of CF patients is the most reliable parameter of the disease (15), the existence of a serum factor(s) in affected and carrier subjects capable of producing in vitro mucociliary disturbances in rabbit tracheal explants seems relevant to some aspects of the pathophysiology of this disease $(10,41)$. Whole sera from CF and obligate heterozygous subjects have been described as promoting the ciliary dyskinesia response in cultured rabbit tracheal epithelium $(10,41)$ due to the presence of ciliary dyskinesia factor(s) (CDF). The response consists of ciliary discordance, mucus secretion and, with additional time, free floating cells $(6,10,41)$, as observed by light microscopy.

CF sera requires calcium to produce or modulate these mucociliary disturbance in the rabbit tracheal bioassay system since these responses can be abolished by the addition of a calcium chelator (6). Ionophore A23187 complexes with divalent cations, especially calcium, and facilitates increased membrane permeability to this ion $(34,36)$. Increased membrane permeability to calcium produced by ionophore A23187 mimicks the CDF response in rabbit tracheal epithelium only in the presence of calcium levels equivalent to or above serum levels (6). These light microscopic findings indicate the importance of calcium as a cofactor in producing the CDF response in the rabbit tracheal bioassay system and suggests that the CF serum and calcium ionophore A23187 may have a similar mechanism of action on rabbit tracheal epithelium at the membrane level by increasing permeability to calcium.

Several investigators found varying ultrastructural changes upon CF serum-induced ciliary dyskinesia in rabbit tracheal epithelium, oyster gills (20), and fresh water mussels (1). In studies of CF sera-treated rabbit tracheal explants done at room temperature for short periods of time, no differences in the ultrastructure of the tracheal epithelium examined were found, whereas the studies using fresh water mussel reported a failure of the CF-treated axonemal microtubules to recover from a "shock-stopped" condition produced by both control and CF sera (1). Baur et al. (3) found a slight swelling of the cilia and an intense mucus secretion upon incubation with $C F$ sera fractions. The purpose of this investigation is to report the comparative ultrastructural changes induced by $\mathrm{CF}$ sera and calcium ionophore A23187 in the rabbit tracheal explant bioassay system and to correlate them with the observed mucociliary disturbances.

\section{MATERIALS AND METHODS} TEST SAMPLES

Venous blood was drawn from five $\mathrm{CF}$-affected individuals and three control subjects. These samples were obtained through the Cystic Fibrosis Outpatient Clinic of the Department 
of Pediatrics, Columbia College of Physicians and Surgeons, New York, New York. Medical histories excluded autoimmune diseases and other pulmonary disease. The blood was allowed to clot at $4^{\circ}$ and, after clot retraction, was centrifuged at $850 \times$ $g$ for $10 \mathrm{~min}$. The serum was collected and stored at $-70^{\circ}$ until use. The status of each donor serum was confirmed by bioassay for ciliary dyskinesia activity in a manner described previously (10).

Basal Medium Eagle with $10 \%$ fetal calf serum (BME) (GIBCO), containing $1.8 \mathrm{mM} \mathrm{CaCl}_{2}$, was tested alone or with ionophore $\mathrm{A} 23187$. An increased concentration of calcium was obtained for testing by the addition of anhydrous calcium chloride to the BME. This concentration of calcium $(5.4 \mathrm{mM})$ was also tested in the bioassay alone or with the addition of calcium ionophore A23187 (Eli Lilly Company). A stock solution containing $10 \mathrm{mg}$ ionophore $/ \mathrm{ml}$ absolute ethanol was prepared and kept frozen in the dark until use. Aliquots of $10 \mu \mathrm{l}$ each of this stock was added to $1 \mathrm{ml}$ BME for assay in the rabbit tracheal system for a final concentration of $2 \times 10^{-3}$ mol. As a control, absolute ethanol $(\mathrm{EtOH})$ was tested at a level of $1 \% \mathrm{v} / \mathrm{v}$ in the bioassay system.

\section{CULTURE OF TRACHEAL TISSUE}

Three male, white New Zealand rabbits, 6-7 pounds in weight, were used for each assay, and a total of nine assays were performed. The trachea was removed and prepared for short term culture as previously described (10). After 2 days of culture at $37^{\circ}$, the tissue explants were examined and the bioassays performed. Explants were examined in the culture flasks by light microscopy (magnification $110 \times$ ) using an inverted Unitron microscope. Pieces with synchronous, actively beating cilia, minimal outgrowth, and freedom from contamination with mucus or hemoglobin were selected for exposure to the test samples. These procedures have been discussed previously $(10,11)$.

\section{LIGHT MICROSCOPY}

Those pieces selected were removed from the flasks and transferred to a glass slide upon which 2 drops of the test sample had been placed. The assay was monitored at $37^{\circ}$ through an inverted microscope. An appropriate border of cilia of each specimen was visualized within $15-30 \mathrm{sec}$ after the tissue was exposed to the test sample. The ciliary action was observed during the succeeding $3 \mathrm{~min}$. The results was recorded and the observation continued for an additional $3 \mathrm{~min}$. For the purposes of these experiments, the usual 3- and 6-min bioassay period was extended to include 15 - and 30 -min intervals.

With each bioassay, a negative control serum was tested to initially evaluate the vitality of the tissue. If no dyskinesia or mucus secretion was observed with the control serum after 6 min, then bioassays of test samples were performed.

\section{ULTRASTRUCTURE AND CYTOCHEMISTRY}

After observation of all test samples by light microscopy, tracheal explants were removed from the test solution at the time intervals described above and fixed in $3 \%$ glutaraldehyde in $0.1 \mathrm{M}$ cacodylate buffer at $4^{\circ}$. The explants were washed and postfixed in $1 \%$ osmium tetroxide in $0.1 \mathrm{M}$ cacodylate buffer. Explants were washed, dehydrated in ethanol, and embedded in Epon 812 (29). Some explants were incubated in the Barka and Anderson modification of the Gomori medium for acid phosphatase activity as previously described $(4,5)$ for $30-60$ min at $37^{\circ}$. These explants were subsequently postfixed and embedded. Sections were cut with a Reichert Ultramicrotome, stained with either uranyl acetate or with uranyl acetate and lead citrate, and examined in a Siemens Elmiskop $1 \mathrm{~A}$ electron microscope.

\section{RESULTS}

\section{EVALUATION OF RABBIT TRACHEAL EXPLANTS AFTER SHORT TERM CULTURE}

The ultrastructural morphology of the epithelial surface of tracheal explants has been explored recently $(2,14,44)$. The rabbit tracheal epithelium consists of ciliated cells, cells characterized by microvilli, and mucous cells. The cells characterized by cilia or microvilli have a lighter cytoplasmic density than the mucous cells (Fig. 1). Cells defining the rabbit tracheal lumen have typical tight junctional complexes. The lateral aspects of the cells are interdigited with little if any observable intracellular space. The only consistent changes found after 2 days of culture were a decrease in the number of mucous granules in the mucous cells, a decrease in the number of mucous cells, and a characteristic increase in secondary lysosomes in the epithelial cells of the explants (Figs. 2 and 3 ). The lysosomes were mostly in the form of dense bodies but some multivesicular bodies were also present. The increase in dense bodies varied from animal donor to animal donor with some rabbit explant epithelium quite marked with lysosomes whereas other explant epithelium had fewer lysosomes (compare Figs. 2 and 3 ). The presence of lysosomes was verified by the distribution of associated acid phosphatase activity (see Fig. 5). The explant epithelial cells did not demonstrate any morphologic parameters of cell injury after 2 days. The axonemal structures were intact, there was no swelling of endoplasmic reticulum or mitochondria, and there was no change in mitochondrial or cytoplasmic density.

\section{SERA-INDUCED CHANGES IN RABBIT TRACHEAL EXPLANT EPITHELIAL CELLS}

Six-minute Exposure to Control and CF Sera in Rabbit Tracheal Bioassay. Tracheal explant epithelial cells exposed to sera from normal subjects for $6 \mathrm{~min}$ at $37^{\circ}$ demonstrated no ultrastructural changes. These cells were morphologically indistinguishable from the tracheal explant epithelial cells cultured in BME. However, tracheal explants exposed to CF sera for 6 min demonstrated a consistent swelling or increase in the size and possibly the numbers of the secondary lysosome or vacuolar system $(18,24)$ in the apical portion of many of the epithelial cells (Fig. 4). The secondary lysosomes induced or enlarged after incubation with CF sera did not take the same form or density as those found in the untreated explants or in explants exposed to control sera. After $6 \mathrm{~min}$ of incubation with $\mathrm{CF}$ sera, the secondary lysosomes of the rabbit tracheal epithelium were characterized by vacuoles that contained numerous vesicles or cell organelles including mitochondria and endoplasmic reticulum or myelin figures (Figs. 4, 6, and 7). The secondary lysosomes that clearly contain cell organelles are classified as autophagic vacuoles based on their morphology and the presence of acid phosphatase activity (Figs. 5 and 6 ), whereas those containing vesicles may be phagocytic vacuoles. Both forms of secondary lysosomes are quite distinctive from the dense bodies observed in the controls. The increase in size or swelling of secondary lysosomes was variable from cell to cell with not all cells demonstrating this change. Other changes observed after 6 nin of exposure to CF sera included an occasional cell that revealed some minor dilation of the apical endoplasmic reticulum. However, no observable changes were found in the structure of the cilia or intercellular space. Mucus secretion was evident by the appearance of profiles of secretory granules fused to lumenal membrane (Fig. 7) or typical profiles characteristic of exocytosis or the fusion of secretory granule membrane to the plasma membrane that occurs during exocrine secretion $(32,33)$.

Fifteen-minute Exposure to Control and CF Sera in Rabbit Tracheal Bioassay. After $15 \mathrm{~min}$ of exposure to either control or CF sera, the epithelial cells demonstrate variable parameters 


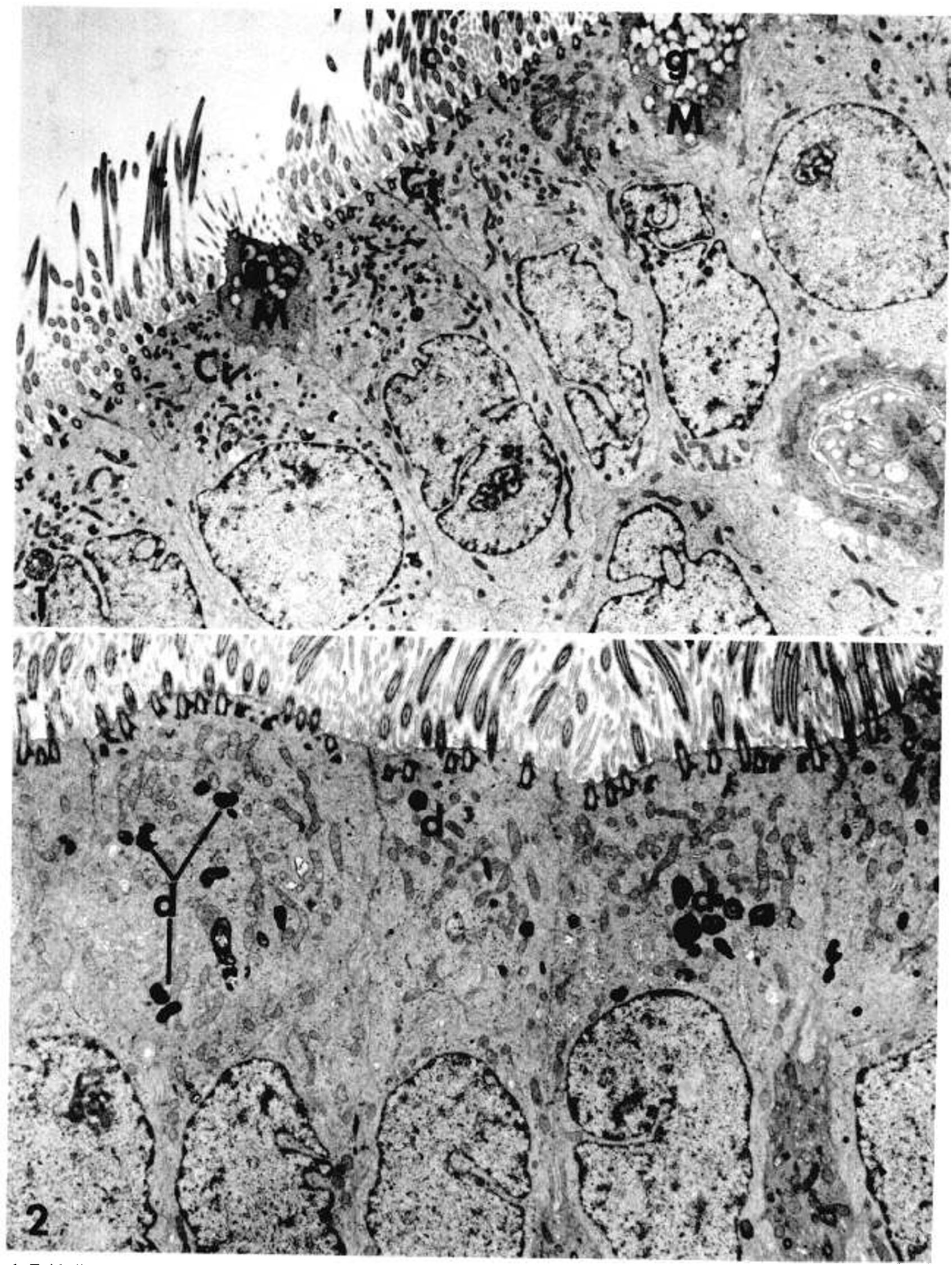

Fig. 1. Epithelial surface of rabbit tracheal explant fixed immediately upon death of the rabbit. The epithelial surface contains numerous ciliated cells ( $\mathrm{Ci}$ ) and mucous cells (M). The ciliated cells are characterized by cilia (c) and numerous mitochondria, whereas the mucous cells have a denser cytoplasm and numerous mucous granules $(\mathrm{g})$. (Magnification $\times 5,000$ )

Fig. 2. After 2 days of culture, there is a decrease in the number of mucous cells and an increase in the number of dense bodies (d) observed in apical portion of the ciliated cells in the rabbit tracheal explant. (Magnification $\times 5,250$ ). 

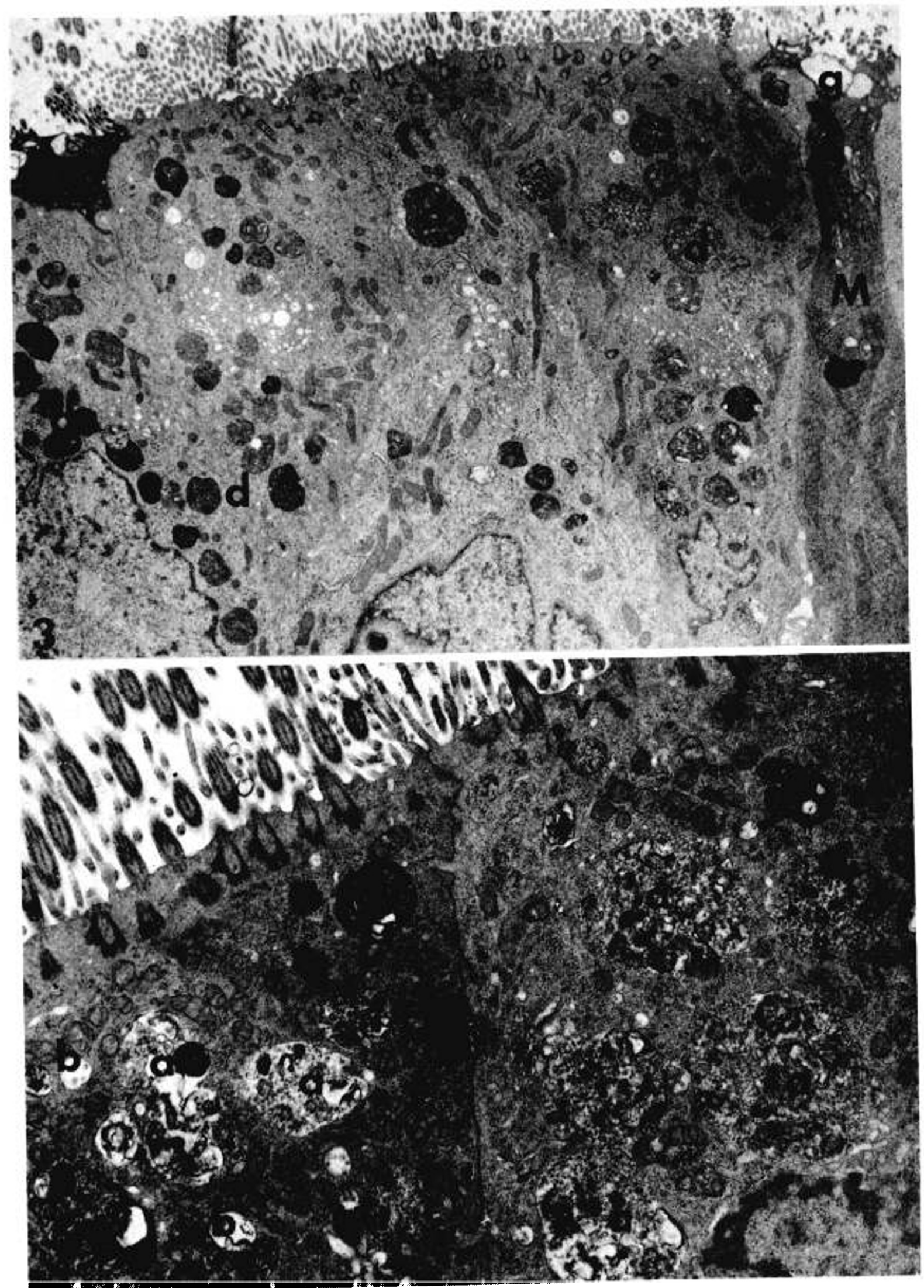

Fig. 3. Epithelial cells of the rabbit tracheal explant after 2 days of culture. This explant is derived from a different rabbit than that in Figure 2 (d) that is observed from donor to donor. However, mucous cells (M) always contain fewer mucous granules $(\mathrm{g})$ after 2 days of culture. (Magnification $\times 9,200$ ).

Fig. 4. Apical portion of ciliated epithelial cells after $6 \mathrm{~min}$ of incubation with CF sera. Most of the lysosomes are in the form of autophagic Fig. 4. Apical portion of cilates (d). The autophagic vacuoles contain numerous small vesicles and cytoplasmic constituents. Apical vesicles (v) and multivesicular bodies (b) are also present. (Magnification $\times 10,000$ ). 


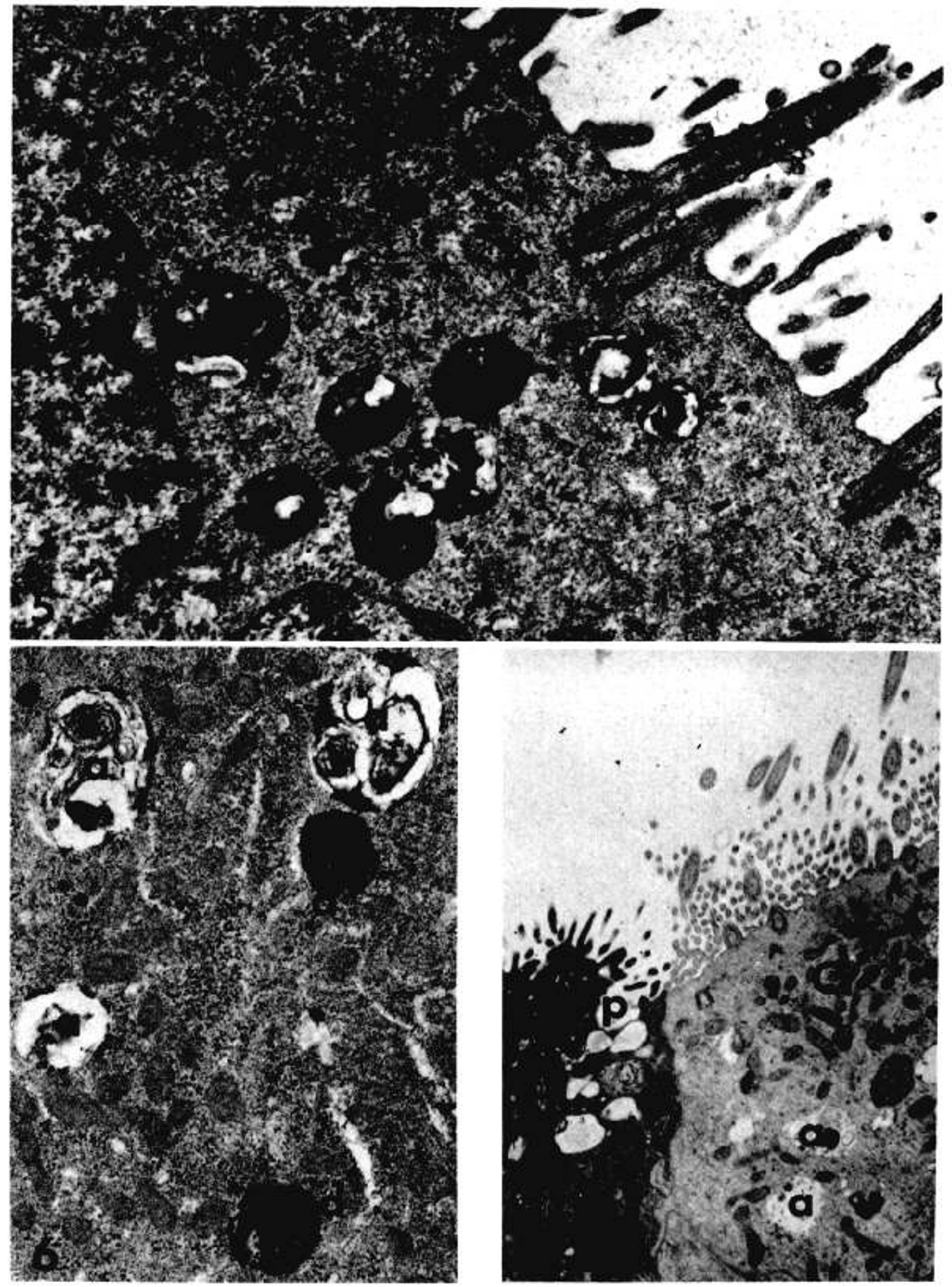

Fig. 5. Apical portion of ciliated epithelial cells of rabbit tracheal explant bioassayed with control sera for 6 min. Numerous dense bodies demonstrated acid phosphatase activity. (Magnification $\times 15,000$ ).

Fig. 6. Apical portion of ciliated epithelial cells of rabbit tracheal explant bioassayed with CF sera for 6 min. Dense bodies (d) and autophagic vacuoles (a) demonstrate acid phosphatase activity. (Magnification $\times 18,000$ ).

Fig. 7. After 6 min of bioassay with CF sera, a mucous cell (M) demonstrates a typical profile or membrane ghost of secretory granule (p) after fusion to lumenal membrane during exocytosis. Adjacent ciliated cell (Ci) contains several autophagic vacuoles (a). (Magnification $\times 10,000)$. 
BOGART ET $A L$.
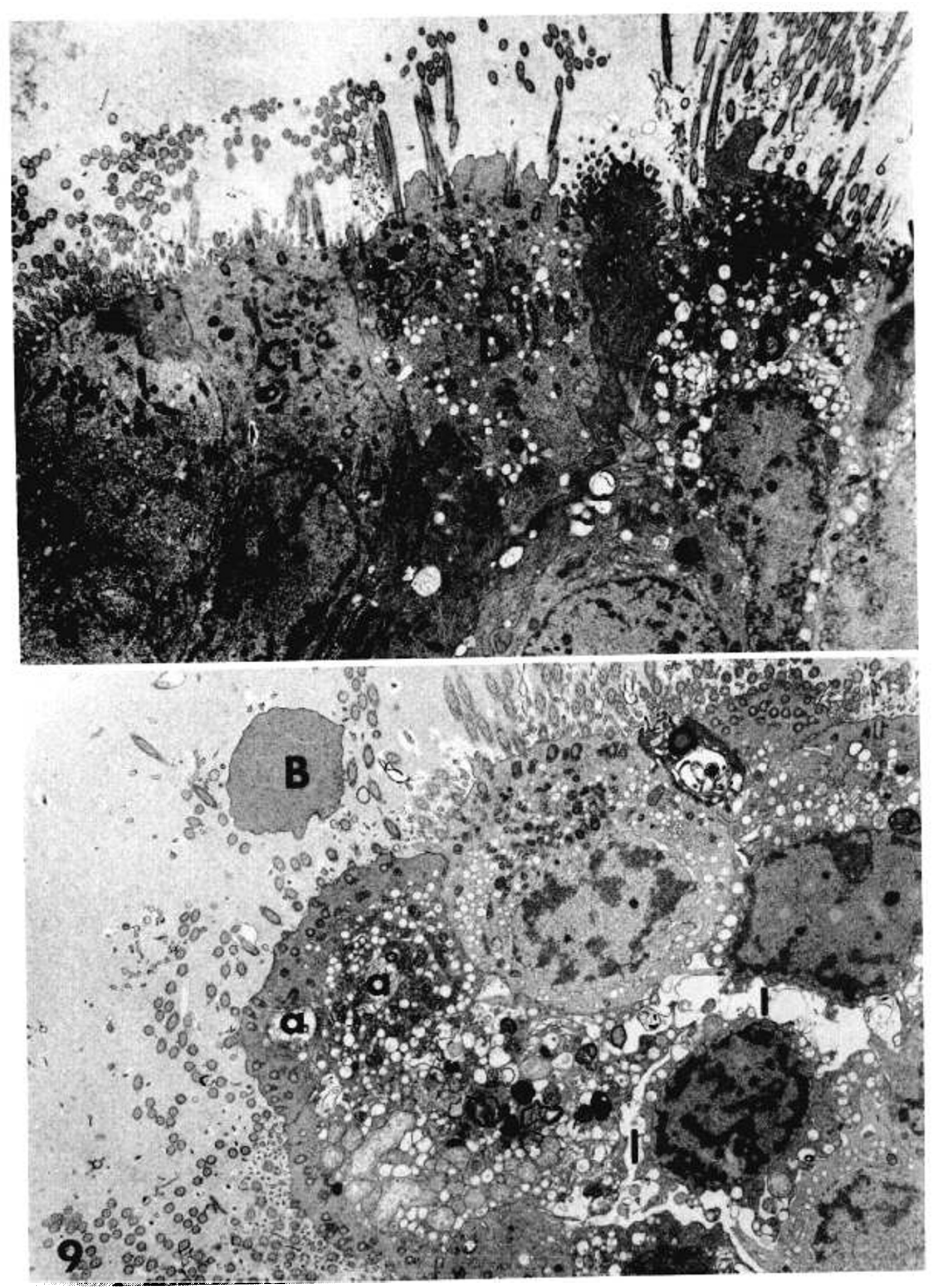

Fig 8. After $15 \mathrm{~min}$ of bioassay with control serum, several ciliated cells (D) contain dilated endoplasmic reticulum and dense swollen mitochondria. Adjacent ciliated cells (Ci) appear to be relatively normal. (Magnification $\times 5,000$ ).

Fig. Af 15 min of bioassay with CF sera, the epithelial cells demonstrate extensive cell injury with dilated endoplasmic reticulum, increased mitochondrial density and swelling, dilation of intercellular space (I), and an apical bleb (B) that appears to have separated and become free floating. Autophagic vacuoles (a) are also present. (Magnification $\times 4,150$ ). 

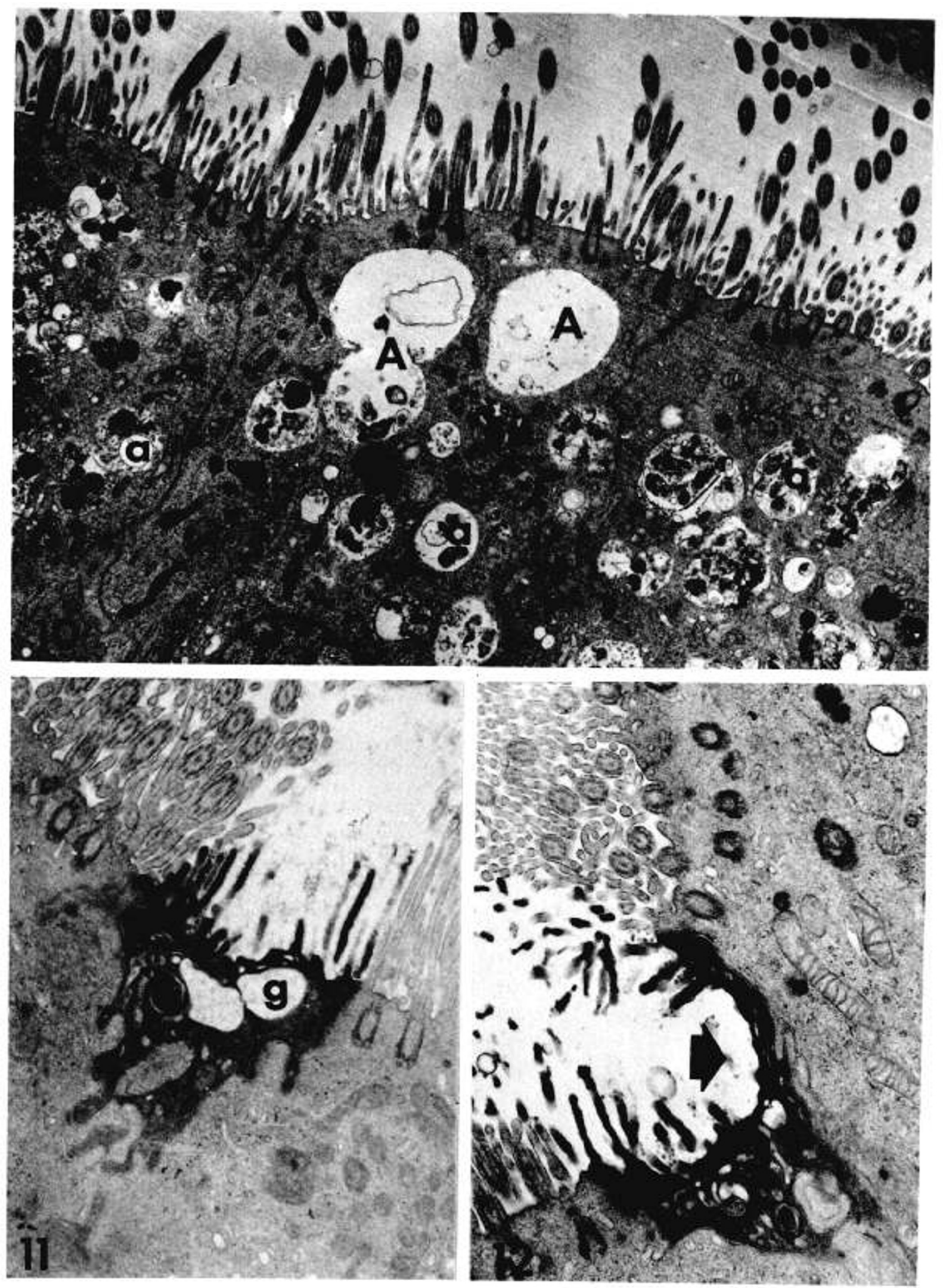

Fig. 10. Apical portion of ciliated cells of rabbit tracheal explant after $30 \mathrm{~min}$ of bioassay with ionophore A23187 in BME with $5.4 \mathrm{mM}$ calcium. Numerous autophagic vacuoles (a) are observed with several appearing to coalesce (A). (Magnification $\times 11,000$ )

Fig. 11. Rabbit tracheal explant bioassayed for $30 \mathrm{~min}$ with $1 \% \mathrm{v} / \mathrm{v}$ ethanol in calcium-enriched BME. Apical portion of mucous cell containing several mucous granules $(\mathrm{g})$. (Magnification $\times 23,000)$.

Fig. 12. Rabbit tracheal explant bioassayed for $30 \mathrm{~min}$ with ionophore A23187 in calcium-enriched BME. Apical portion of mucous cell demonstrating enlarged concave surface due to profiles of released secretory granules fused to lumenal membrane (arrow) after exocytosis.
(Compare with Fig. 11.) (Magnification $\times 20,000)$. 
of cell injury, including swelling of endoplasmic reticulum and mitochondria, dilation of intercellular space, and increased mitochondrial density. These changes occur to some degree in both CF and control sera-treated tracheal epithelium. However, less damage is observed in the control sera-treated tracheal epithelium in both degree of damage exhibited by individual cells and the number of cells damaged. The control epithelium demonstrated foci of damaged cells with structurally normal cells immediately adjacent (Fig. 8). In addition to the swelling of the endoplasmic reticulum and alterations in the mitochondrial density, epithelial cells exposed to CF sera demonstrated extensive alteration in the architecture of the tissue (Fig. 9). There was gross dilation of intercellular space, blebing or ballooning of apical cytoplasm, and exfoliation of cells as demonstrated by the presence of many free floating single cells.

Thirty-minute Exposure to Control and CF Sera in Rabbit Tracheal Bioassay. After $30 \mathrm{~min}$ of exposure to either control or CF sera, the cell damage began to converge with increasing numbers of cells demonstrating the changes characteristic of extensive cell damage, including dilation of endoplasmic reticulum, increased mitochondrial density and swelling, blebing and ballooning of apical cytoplasm, clumping of chromatin material, and extensive exfoliation of epithelial cells.

\section{IONOPHORE A23187-INDUCED CHANGES IN EXPLANT EPITHELIAL CELLS}

Small doses of ethanol vehicle $(1 \% \mathrm{v} / \mathrm{v})$ added to $\mathrm{BME}$ had no effect on the ultrastructure of the rabbit tracheal epithelium (Fig. 11). Addition of ionophore A23187 to BME with an elevated calcium level of $5.4 \mathrm{mM}$ revealed a swelling or increase in secondary lysosomes after 15 and $30 \mathrm{~min}$ of incubation (Fig. 10). The secondary lysosomes were observed in the cells characterized by both cilia and microvilli and demonstrated acid phosphatase activity. These secondary lysosomes resembled those observed in CF sera-treated tracheal epithelia, but were found in greater numbers in many epithelial cells. The general ultrastructure of the epithelium was good with little or no accompanying swelling of intercellular spaces, changes in cytoplasmic density or swelling of endoplasmic reticulum or mitochondria. No evidence of cell injury accompanied the induction of autophagic vacuoles by ionophore A23187 in the epithelial cells. There was an increase in secretion by the mucous cells as demonstrated by the deep crater-like profiles produced by rapid exocytosis of secretory granules (compare Figs. 11 and 12).

\section{DISCUSSION}

Tracheal epithelium has been studied extensively in culture $(2,14,44)$. The ultrastructural alterations observed after short term culture of rabbit tracheal epithelium compare favorably with changes reported in the extensive literature on many different species $(2,14,44)$. In the present study, the major alterations observed after short term culture are the presence of a variable number of dense autophagic bodies in epithelial cells and a decrease in the number of mucous granules and mucous cells. It has been suggested that these changes may be due to autophagia and are common accompaniment of organ culture $(2,44)$.

Our previous studies have demonstrated that the CDF response in the rabbit tracheal bioassay system consists of a discordance in the ciliary beating pattern and mucus secretion $(6,10,11)$. Light microscopic studies revealed alterations of the metachronal wave of the tracheal cilia produced by CF sera and ionophore A23187 (6). Some representation of an altered metachronal wave was sought on the ultrastructural level. However, there was no discernable alteration of cilia morphology representative of the ciliary dyskinesia observed by light microscopy. Previous ultrastructural studies (20) of the rabbit tracheal bioassay system observed no changes induced by $\mathrm{CF}$ sera after $6 \mathrm{~min}$ at room temperature. However, several light microscopic studies $(8,10)$ of the rabbit tracheal bioassay system revealed that no ciliary dyskinesia is observed during this short time period at room temperature. Other studies using fresh water mussel gill cilia (1) as an experimental model revealed that both control and CF sera produced a loss of the axonemal structure or "shock-stopped" condition. Gill cilia exposed to control sera were capable of reorganizing normal axonemal microtubule structure, whereas gill cilia exposed to CF sera could not reorganize their axonemal microtubule structures or return to an active form. It was thought that the sera altered membrane function in some unknown manner. Ultrastructural study of the oyster gill model incubated with serum fractions from CF and control subjects demonstrate an extensive mucus secretion (3) similar to that reported here.

The changes induced by $\mathrm{CF}$ sera after $15 \mathrm{~min}$ are typical of cell injury $(7,42,43)$. However, less cell damage is observed in control sera-treated tracheal explants in both degree of cell damage and the number of cells damaged after $15 \mathrm{~min}$. The subsequent cell injury to the rabbit tracheal epithelium may be caused by any number of factors, including anoxea produced by $100 \%$ sera in culture $(18,42)$. The extensive cell injury produced by normal serum and at an accelerated rate by $C F$ serum has been reported previously (7). Several investigators have noted the cytotoxic effect of serum on the rabbit tracheal bioassay system and proposed that it excluded a reproducible assay. The ultrastructural criteria of cell injury are not observed during the testing period of 3-6 min, but only after $15 \mathrm{~min}$. The extensive cell injury to the tracheal epithelium indicates that the ciliary dyskinesia reaction is only valid in the rabbit tracheal bioassay system if read at short time intervals in the range of 3$9 \mathrm{~min}$ at $37^{\circ}$ as stressed by Conover et al. (10). Longer time intervals lead to a sera-induced cell injury and makes the results of the rabbit tracheal bioassay system unreliable at these time periods.

Both CF sera and calcium ionophore A23187 characteristically induce either a swelling or an increase in the secondary lysosomes in the epithelium of the rabbit tracheal bioassay system. Many of the secondary lysosomes contain mitochondria and endoplasmic reticulum as well as acid phosphatase activity and therefore fall into the category of autophagic vacuoles. These vacuoles may result from either an expansion of the existing dense bodies due to an increase in autophagic activity or to a swelling of the existing vacuoles. Autophagia accompanies many physiologic and pathologic phenomena, including remodeling of the cells during differentiation, involution, and metamorphosis (18); reorganization of the cell during hypersecretion $(5,19)$; stimulation of the liver cell by glucagon $(13)$; and many experimental examples of sublethal and lethal cell injury $(18,42,43)$. However, the increase in the autophagic vacuoles and other secondary lysosomes may result in a swelling of these structures. Several authors $(30,35,40)$ have noted swelling of the Golgi complex in many cell types after incubation with the ionophore X537A. Mira-Moser et al. (30) postulated that the accompanying swelling of the Golgi may be due to an influx of potassium ions into this organelle and their subsequent osmotic effects. In either case, the increase in the secondary lysosomes or autophagic vacuoles in rabbit tracheal epithelial cells and secretion of mucus after incubation with either $\mathrm{CF}$ sera or with calcium ionophore A23187, but not by normal sera or the ethanol vehicle control after 6 min of bioassay indicates that the CF factor(s) may be acting on the rabbit tracheal epithelial membranes in an analogous manner to ionophore A23187. Ionophore A23187 is an antibiotic that forms lipophilic complexes with cations, has a high calcium specificity, and transports calcium across membranes $(34,36,46)$. It is an important experimetnal tool in determining the calcium requirements for many physiologic systems, including secretion by salivary gland slices $(38)$, pancreas $(17)$, and mast cells $(9,25)$. Motokawa and Satir $(31,37)$ observed that increasing cellular calcium in mussel gill cilia or mollusc gill cilia either with the 
calcium ionophore A23187 or injury produced an altered ciliary function. Studies on microtubules, the biologic subunit of the cilia, have demonstrated that the integrity of these structures are sensitive to increases in cytoplasmic calcium levels which impair microtubule function $(21,22,26,27,39,45)$. Our previous light microscopic studies (6) have demonstrated the calcium requirement of the induction of ciliary dyskinesia response by CF sera and that ionophore A23187 can mimic the ciliary dyskinesia response in the rabbit tracheal bioassay system only in the presence of the elevated calcium levels. In addition, both CF sera and ionophore A23187 produce either a swelling or increase in secondary lysosomes and an increase in mucus secretion in the rabbit tracheal bioassay system. These latter phenomena are morphologic parameters of either altered membrane function or the manner in which the tracheal epithelial cells respond to such an increased membrane permeability to calcium. These considerations support the view that increased membrane permeability to calcium may be important in the ciliary dyskinesia reaction, mucus secretion, and the swelling or increases in autophagic vacuoles in the rabbit tracheal bioassay system. CF sera factor(s) may be acting on cell membranes to produce altered membrane function(s), one of which is an increase in membrane permeability to calcium, and that such changes may be relevant to the pathophysiology of the disease.

\section{CONCLUSION}

Rabbit tracheal explants in culture for 2 days demonstrate an increase in dense bodies and a decrease in mucous granules in the mucous cells and a decrease in the number of mucous cells. Both CF sera and calcium ionophore A23187 induce a swelling or an increase in the size and number of autophagic vacuoles and mucus secretion by the tracheal explant epithelium. Both $\mathrm{CF}$ and control sera produce a cytotoxic effect on the epithelial cells, but only after the termination of the normal bioassay time period. Cell injury includes dilation of endoplasmic reticulum, changes in mitochondria structure and density, enlargement of intercellular space, blebbing of apical cytoplasm, and exfoliation of cells. This process occurs only after the termination of the normal time period of the bioassay and appears to be accelerated by CF sera. No comparable cell injury is observed in the rabbit tracheal explants exposed to the calcium ionophore $A 23187$ or the vehicle control (EtOH), even after $30 \mathrm{~min}$.

These results indicate that calcium may be an important cofactor in the production of the CF sera-induced ciliary dyskinesia response in the rabbit tracheal bioassay. CF serum factor(s) may be acting at the level of the cell membranes to produce altered function and membrane permeability that may be related to the cytopathology of this disease.

Notes Added in Proof. After we submitted this paper, Czegledy-Nagy, E., and Sturgess, J. M. (Lab. Invest., 35: 588 (1976)) reported optical and scanning electron microscopic investigations that demonstrated a CF serum factor(s) mediated increase in mucus secretion and cell damage in the rabbit tracheal bioassay system, while Wilson, G. B., Monsher, M. T., and Fudenberg, H. H. (Pediat. Res., 11: 143 (1977)) reported ciliary dyskinesia, mucus secretion, and extrusion of single ciliated cells in a modified rabbit tracheal bioassay.

\section{REFERENCES AND NOTES}

1. Adshed, P. C., Martinez, J. R., Kilburn, K. H., and Hess, R. A.: Ciliary inhibition and axonemal microtubule alterations in freshwater mussels. Ann. N. Y. Acad. Sci., 253: 192 (1975).

2. Barrett, L. A., McDowell, E. M., Frank, A. L., Harris, C. C., and Trump, B. F.: Long-term organ culture of human bronchial epithelium. Cancer Res., 36: 1003 (1976).

3. Baur, P. S., Brinkley, B. R., and Bowman, B. H.: Effect of cystic fibrosis serum ciliary inhibitor on oyster gill ultrastructure: Analysis by scanning and transmission electron microscopy. Texas Rep. Biol. Med., 34: 1, (1976)

4. Bogart, B. I.: The fine structural localization of alkaline and acid phosphatase in the rat submandibular gland. J. Histochem. Cytochem., 16: 572 (1968).
5. Bogart, B. I.: Secretory dynamics of the rat submandibular gland. An ultrastructural and cytochemical study of the isoproterenol-induced secretory cycle. J. Ultrastruct. Res., 52: 139 (1975).

6. Bogart, B. I., Conod, E. J., and Conover, J. H.: The biological activities of cystic fibrosis serum. 1. The effect of cystic fibrosis sera and calcium ionophore A23187 on rabbit tracheal explants. Pediat. Res. (In press).

7. Cherry, J. D., Roden, V. J., Rejent, A. J., and Dorner, R. W.: The inhibition of ciliary activity in tracheal organ cultures by sera from children with cystic fibrosis and control subjects. J. Pediat., 79: 937 (1971).

8. Cheung, A. T. W., and Jahn, T. L.: High speed cinemicrographic studies on rabbit tracheal (ciliated) epithelia: Cytolytic effect of cystic fibrosis serum on tracheal epithelial cells. Pediat. Res. 10:144 (1976).

9. Cochrane, D. E., and Douglass, W. W.: Calcium induced extrusion of secretory granules (exocytosis) in mast cells exposed to $48 / 80$ or the ionophores A23187 and X-537A. Proc. Natl. Acad. Sci. U. S. A., 71: 408 (1974).

10. Conover, J. H., Bonforte, R. J., Hathaway, P., Paciuc, S., Conod, E. J., Hirshorn, K., and Kopel, F. B.: Studies on ciliary dyskinesia factor in cystic fibrosis. I. Bioassay and heterozygote detection in serum. Pediat. Res., 7: 220 (1973)

11. Conover, J. H., Conod, E. J., and Hirschhorn, K.: On the nature of the defect in cystic fibrosis. Texas Rep. Biol. Med. 34: 45, (1976).

12. Daems, W. T., Wisse, E., and Brederoo, P.: Electron microscopy of the vacuolar system. In: J. T. Dingle and $H$. B. Fell: Lysosomes in Biology and Pathology, Vol. 1, p. 64 (North-Holland Publishing Co., Amsterdam, 1969).

13. Deter, R. L., and DeDuve, C.: Influence of glucagon, an inducer of cellular autophagy on some physical properties of the rat liver lysosomes. J. Cell Biol. 33: 437 (1967)

14. Dirksen, E. R., and Crocker, T. T.: Ultrastructural alterations produced by polycyclic aromatic hydrocarbons on rat tracheal epithelium in organ culture. Cancer Res., 28: 906 (1968).

15. Di Sant'Agnese, P. A., Darling, R. C., Perer, G. A., and Shea, E.: Abnormal electrolyte composition of sweat in cystic fibrosis of the pancreas. Pediatrics 12: 549 (1953).

16. Di Sant'Agnese, P. A., and Talamo, R. C.: Pathogenesis and physiopathology of cystic fibrosis of the pancreas: Fibrocystic disease of the pancreas (mucoviscidosis). N. Engl. J. Med. 277: 1287, 1343, 1399 (1969).

17. Eimerl, S., Savion, N., Heichal, O., and Selinger, Z.: Induction of enzyme secretion in rat pancreatic slices using the ionophore $A 23187$ and calcium. J. Biol. Chem. 249: 3991 (1974).

18. Erricsson, J. L. E.: Mechanism of cell autophagy. In: J. T. Dingle and H. B. Fell: Lysosomes in Biology and Pathology, Vol. 2, p. 345 (North-Holland Publishing Co., Amsterdam, 1969).

19. Farquhar, M. J.: Lysosome function in regulating secretion: Disposal of secretory granules in cells of anterior pituitary gland. In: J. T. Dingle and H. B. Fell: Lysosomes in Biology and Pathology, Vol. 2, p. 462 (NorthHolland Publishing Co., Amsterdam, 1969).

20. Farrell, P. M., Fox, G. M., and Spicer, S. S.: D.termination and characterization of ciliary ATPase in the presence of serum from cystic fibrosis patients. Pediat. Res. 10: 127 (1976).

21. Gallin, J. I., and Rosenthal, A. S.: The regulatory role of divalent cations in human granulocyte chemotaxis: Evidence for an association between calcium exchanges and microtubule assembly. J. Cell Biol. 62: 594 (1974).

22. Gillespie, E.: Cholchine binding in tissue slices. J. Cell Biol., 50: 544, (1971).

23. Ginn, F. L., Shelburne, J. D., and Trump, B. F.: Disorders of cell volume I. Effects of inhibition of plasma membrane adenosine triphosphatase with oubain. Amer. J. Pathol. 53: 1041 (1968).

24. Jacques, P. J.: Endocytosis. In: J. T. Dingle and H. B. Fell: Lysosomes in Biology and Pathology, Vol. 2, p. 395 (North-Holland Publishing Co., Amsterdam, 1969).

25. Kagayama, M., and Douglas, W. W.: Electron microscope evidence of calcium-induced exocytosis in mast cells treated with $48 / 80$ or ionophore A23187 and X537A. J. Cell Biol. 62: 519 (1974)

26. Kirschna, M. W., and Williams, R. C.: The mechanism of microtubule assembly in vitro. J. Supramol. Struct. 2: 412 (1974).

27. Kuriyama, R., and Sakai, H.: Viscometric demonstration of tubulin polymerization. J. Biochem. Tokyo, 75; 463 (1975).

28. Lubeck, C. C.: Cystic fibrosis of the pancreas. In: J. B. Stanbury, J. B. Wyngaarden, and D. S. Fredrickson: Metabolic Basis of Inherited Disease, Ed. 3, p. 1605 (McGraw-Hill, New York, 1972).

29. Luft, J. H.: Improvements in epoxy resin embedding methods. J. Biophys. Biochem. Cytol., 9: 409 (1961).

30. Mira-Moser, F., Schofield, J. G., and Orci, L.: Modification in the release of rat growth hormone in vitro and the morphology of rat anterior pituitaries incubated in various ionophores. Europ. J. Clin. Invest., 6: 103, 1976.

31. Motokawa, T., and Satir, P.: Laser-induced spreading arrest of mytilus gill cilia. J. Cell Biol. 66: 377 (1975).

32. Neutra, M., and Leblond, C. P.: Synthesis of the carbohydrate of mucus the Golgi complex as shown by electron microscope in radioautography of goblet cells from rats injected with glucose- $\mathrm{H}^{3}$. J. Cell Biol. 30:119 (1966).

33. Palade, G. E.: Functional changes in the structure of cell components. In: $\mathrm{T}$. Hayashi: Subcellular Particles, p. 64 (Ronald Press, New York, 1959).

34. Pressman, B. C.: Properties of ionophores with broad range cation selectivity. Fed. Proc., 32: 1698 (1973).

35. Ravazzola, M.: Golgi complex alterations induced by $\mathrm{X} 537 \mathrm{~A}$ in chief cells of rat parathyroid gland. Lab. Invest. 35: 425, (1976). 
36. Reed, P. W., and Lardy, H. A.: A23187: A divalent cation ionophore. J. Biol. Chem., 247: 6970 (1972).

37. Satir, P.: Ionophore-mediated calcium entry induces mussel gill ciliary arrest. Science, 190: 586 (1975).

38. Selinger, Z., Eimerl, S., and Schramm, M.: A calcium ionophore simulating the action of epinephrine on the $\alpha$ adrenergic receptor. Proc. Natl. Acad. Sci. U.S. A., 71: 128 (1974)

39. Shelanski, M. L., Gaskin, F., and Cantor, C. R.: Microtubule assembly in the absence of added nucleotides. Proc. Natl. Acad. Sci. U. S. A., 70: 765 (1973).

40. Somlyo, A. P., Garfield, R. E., Chacko, S., and Somlyo, A. V.: Golgi organelles response to the antibiotic X537A. J. Cell Biol., 66: 425, (1975).

41. Spock, A., Heick, H. M. C., Cress, A., and Logan, W. S.: Abnormal serum factor in patients with cystic fibrosis of the pancreas. Pediat. Res. 1: 173 (1967)

42. Trump, B. F., and Arstila, A. U.: Cell membranes and disease processes. In B. F. Trump and A. U. Arstila: Pathobiology of Cell Membranes, p. 1 (Academic Press, New York, 1975)

43. Trump, B. F., Crocker, B. D., and Mergoner, W. J.: The role of energy metabolism, ion and water shifts in the pathogenesis of cell injury. In: $G$ W. Ricter and D. G. Scarpelli: Cell Membranes: Biological and Pathological

Copyright (ㅇ 1978 International Pediatric Research Foundation, Inc $0031-3998 / 78 / 0012-0001 \$ 02.00 / 0$
Aspects, p. 84 (The Williams \& Wilkins Co., Baltimore, 1971).

44. Trump, B. F. McDowell, E. M., Barret, L. A., Frank, A. L., and Harris, C. C.: Studies of ultrastructure, cytochemistry and organ culture of human bronchial epithelium. In: F. Karbe and J. E. Parks: Experimental Lung Cancer Carcinogenesis and Bioassay, p. 548, (Springer-Verlag, New York, 1974).

45. Weisenberg, R. C.: Microtubule formation in vitro in solutions containing low calcium concentrations. Science, 177: 1104 (1972).

46. Wong, D. T., Wilkinson, J. R., Hanill, R. L., and Horng, J. S.: Effect of antibiotic ionophore A23187 on oxidative phosphorylation and calcium transport of liver mitochondria. Arch. Biochem. Biophys. 156: 578 (1973)

47. Dr. James Conover is the recipient of Cystic Fibrosis Foundation Research Scholar Award.

48. This work was supported in part by grants from the National FoundationMarch of Dimes (1-392) and by the Cystic Fibrosis Foundation.

49. Requests for reprints should be addressed to: Bruce I. Bogart, Ph.D., New

York University Medical Center, Department of Cell Biology, 550 First Avenue, New York, New York 10016 (USA)

50. Received for publication October 11, 1976

51. Accepted for publication April 26, 1977.

Printed in U.S.A.

Pediat. Res. 12: 24-26 (1978)

Absorption

intestinal osmolality

intraluminal water content polyethylene gylcol

polymerized glucose

\title{
Intestinal Osmolality and Carbohydrate Absorption in Rats Treated with Polymerized Glucose
}

\author{
FREDRIC DAUM, ${ }^{(8)}$ MICHAEL I. COHEN, HELEN MCNAMARA, AND LAURENCE FINBERG \\ Department of Pediatrics, Montefiore Hospital and Medical Center, Albert Einstein College of Medicine, Bronx, \\ New York, USA
}

\section{Summary}

The intestinal osmolal physiology and absorption of comparable preparations of polymerized glucose and glucose were evaluated in isolated segments of rat duodenum. The acute rise in the osmolality of the succus entericus after $5 \%$ polymer injections $(298 \mathrm{mOsm} / \mathrm{kg}$ at $3 \mathrm{~min}, 311 \mathrm{mOsm} / \mathrm{kg}$ at $30 \mathrm{~min}$ ) was significantly less than that noted after $5 \%$ glucose (387 $\mathrm{mOsm} / \mathrm{kg}$ at $3 \mathrm{~min}, 351 \mathrm{mOsm} / \mathrm{kg}$ at $30 \mathrm{~min}$ ). At $60 \mathrm{~min}$ a steady state had been established and no significant difference was found. Ten percent polymer was superior to $10 \%$ glucose as it also produced a lower luminal osmolality $(351 \mathrm{mOsm} / \mathrm{kg}$ versus $427 \mathrm{mOsm} / \mathrm{kg}$ at $30 \mathrm{~min}$ ). Luminal polyethylene glycol concentrations revealed comparable increases in intraluminal water content after $10 \%$ polymer and $5 \%$ glucose $(22 \%$ versus $25 \%$ al: $30 \mathrm{~min}$ ). After polymer injections, 4 times as much glucose was present in the mucosa as in the succus, whereas, after $5 \%$ glucose injections, a high concentration of glucose remained in the succus.

These results indicate that polymer solutions produce lower luminal osmolality than glucose solutions of similar weight. Additionally, enhanced glucose absorption by the mucosal cell is suggested in animals injected with polymer. Polymerized glucose should, therefore, provide twice the calories of glucose without a disparate increase in the intestinal osmolality and intraluminal diffusion of extracellular water.

\section{Speculation}

A polymerized glucose preparation, when administered orally, produces a lower immediate intraluminal solute content and osmolality than a glucose solution of the same concentration by weight when each has comparable electrolytes. Hydrolysis of the polymer within the intestinal lumen and on contact with the brush border of the intestine provides nutrient without increase in water movement into the proximal small bowel. Because of these properties, such a polymer may be useful in the oral nutritional rehabilitation of neonates and infants with diarrhea. It remains to be seen whether the pathogenesis of the diarrheal state may also prove to be of significance in determining the beneficial effect of this therapy.

Polymerized glucose represents a carbohydrate source with low electrolyte and mineral content prepared by acid-enzyme hydrolysis of selected cornstarch. The process yields a hydrolysate with $80 \%$ amylose, $20 \%$ amylopectin, and small amounts of glucose, maltose, and isomaltose. The polymer is predominantly medium chain length glucose moieties although a variety of lengths are present. Free glucose represents less than $2 \%$ of all the carbohydrate present whereas a chain length of 5-9 glucose units comprises almost $50 \%$ of the polymer. The polymers are mainly linear in their spatial configuration. The glucose 